\title{
Kroppen i lærebøker i videregående skole - et innblikk i kroppsøvingsfagets ideologiske kamp
}

\author{
Cathrine Berger Myreng, ${ }^{1 \star}$ Gunn Helene Engelsrud ${ }^{2}$ og \\ Glenn Øvrevik Kjerland ${ }^{2}$ \\ ${ }^{1}$ Valdres videregående skole, Norge; ${ }^{2}$ Høgskulen på Vestlandet, Norge
}

\section{Sammendrag}

Artikkelen omhandler hvilke kroppsdiskurser som framtrer i lærebøker som brukes i kroppsøvingsfaget $\mathrm{i}$ videregående skole, og hvordan disse kroppsdiskursene inngår i ideologiske kamper om innflytelse og dominans når det gjelder kroppsforståelsen i kroppsøvingsfagets sosiale praksis.

Vi bruker Norman Faircloughs kritiske diskursanalyse til å undersøke hvordan kroppen framstilles i tekst, bilder og figurer i lærebøkene, og hvordan kroppsdiskursene som inkluderes, og de som ekskluderes, inngår i en ideologisk kamp om hvordan kroppen skal omtales og skrives fram i kroppsøvingsfaget.

Analysen av lærebøkene avdekket tre framtredende kroppsdiskurser. De er den idrettsaktive kroppen, den biologiske kroppen og den atletiske kroppen, som sammen utgiør rammen for en idealkropp. Andre kropper, som kroppen med ulikhet i funksjoner, den overvektige kroppen, kvinnekroppen og den etniske kroppen, teller kun med dersom de kan plasseres i den idrettsaktive eller atletiske kroppsdiskursen.

Lærebøkene vi har analysert, bidrar til at kroppsforståelsene i kroppsøvingsfaget framstår som normale i fagets sosiale praksis, noe som igjen henger sammen med dominerende idretts- og prestasjonsdiskurser som har kommet til syne i undersøkelser av fagets sosiale praksis over tid.

Nøkkelord: kropp; kritisk diskursanalyse; diskursorden; ideologi og lerebok

\begin{abstract}
The body discourse promoted in physical education textbooks

This article is an analysis of the body discourses that are promoted in physical education textbooks for high school students, and a discussion of how these discourses are part of the larger debate about the nature of the body in the social practice of physical education.

We use Norman Fairclough's critical discourse analysis to investigate how the body is depicted in text, photos, and illustrations in the textbooks, and how the choice of which body discourses to include and which to exclude is part of an ideological struggle over how to understand and describe the body in physical education.
\end{abstract}




\section{B. Myreng, G. H. Engelsrud E G. Ø. Kjerland}

Our analysis of the textbooks revealed three prominent body discourses: the sports-active body, the biological body and the athletic body. Taken together, these three types set the standard for the ideal body as defined by the physical education textbooks. Bodies that are disabled, overweight, female or belonging to an ethnic minority are discussed and depicted in the textbooks only insofar as they can be included in the sports-active or athletic discourses.

The textbooks we have analyzed contribute to a normalization of physical education's body discourses within its social practices. We see this as a perpetuation of non-inclusive standards and ideals that previous studies have shown to be dominant in the social practice of sports and physical education over time.

Keywords: body; critical discourse analysis; discourse order; ideology and textbooks

Mottatt: Mars, 2021; Antatt: November, 2021; Publisert: Desember, 2021

\section{Innledning}

Formålet med artikkelen er å undersøke hvilke kroppsdiskurser som er de gjeldende i lærebøkene til kroppsøvingsfaget i videregående skole, og vi spør om en slik analyse kan belyse og gi innsikt i hvilke kroppsdiskurser som har innflytelse på fagets sosiale praksis. Ifølge Fairclough (2010) er diskurser ulike måter å strukturere kunnskap og sosial praksis på. I hans teori inngår tekstene i en sosial praksis, og beveger seg på den måten ut over tekstene i seg selv. Fairclough argumenterer for å undersøke tekster som en sosial praksis, konstituert gjennom både det talte og skriftlige. I sitt maktkritiske perspektiv henviser Fairclough til ulike diskurser, ideologiske kamper, hvor noen diskurser dominerer og andre ekskluderes. I vår studie nyttes Faircloughs $(2003,2010)$ tilnærming for å undersøke hvilke kroppsdiskurser som framtrer i lærebøkene i kroppsøving, og hvordan de er med på å konstituere kroppsforståelser i fagets sosiale praksis. I analysen og diskusjonen spør vi også om hvilke kroppsdiskurser som inkluderes og hvilke som ekskluderes, og hvordan de inngår i en ideologisk kamp om hvordan kropper omtales og skrives fram i kroppsøvingsfaget.

I forskning om kroppsøvingsfaget beskrives flere kroppsdiskurser som både er med på å forme den sosial praksis og konkurrere om innflytelse (Augestad, 2003; Kirk, 2010; Moen \& Rugseth, 2018; Aasland, 2019). Flere hevder imidlertid at mangfoldet av kropper ikke har vært respektert eller prioritert i kroppsøvingsfagets sosiale praksis. Snarere har det å disiplinere og normalisere sunne, atletiske, slanke og idrettspresterende kropper vært framtredende (Augestad, 2003; Kirk, 2010), og kroppsøvingsfaget har historisk sett vært formet og preget av de sosiale og disiplinerende strukturene $\mathrm{i}$ samfunnet. Svendby (2013, s. 215) skriver:

... at måten faget konstrueres og reproduseres på begrenser mulighetene for å skape et inkluderende læringsmiljø. Det blir spesielt fremtredende ved at kroppsøvingsfaget domineres av en idretts- og prestasjonsdiskurs med gitte prestasjonsformer og bevegelsesløsninger, og en aktivitets- og helsediskurs som bidrar til at faget reproduserer bestemte verdier [...] Det fører til at en bestemt evne ("ability»), bestemte ferdigheter og visse typer kropper verdsettes og favoriseres, mens andre marginaliseres og utelukkes. 
Svendsen og Svendsen (2017) støtter opp under en forståelse av et skolefag dominert av en idretts-, prestasjons-, aktivitets- og helsediskurs, som er med på å avgjøre hvilke typer kropper som favoriseres, og hvilke som marginaliseres. Med sin analyse av lærebøker i kroppsøvingslærerutdanningen viser de at tekstene medvirker til å konstruere og reprodusere bestemte verdier i faget. Lærebøkene er sentrale formidlere av fagstoff, verdier og ideologier, og «rommer diskurser om kroppen, bevegelse og kroppsøving som et fag i skolen» (Svendsen \& Svendsen, 2017, s. 481, egen oversettelse). Andre viser til samme tendenser i undervisningen i faget. Kirk (2010), Tinning (2010) og Sæle (2017) skriver at kroppsøvingsfaget preges av en aktivitetsdiskurs, en prestasjonsdiskurs og en konkurransediskurs, der undervisningen er rettet mot gjøring av aktiviteter. Prestasjoner står i fokus og innholdet er idrettspreget. Det indikeres i forskning om kroppsøvingsfaget at det domineres av disiplinerende og normaliserende kropper innrammet i fagets idrettsdiskurs, prestasjonsdiskurs, aktivitetsdiskurs og helsediskurs; kropper som passer inn i verdsettingskulturer preget av sunne, vakre, atletiske, slanke og helst hvite kropper (Azzarito, 2009; Walseth \& Tidslevold, 2020).

I kroppsøving er det mange elementer som influerer på og tar del i fagets praksis og utvikling. Blant dem er utdanningspolitiske dokumenter, læreplaner og rammeplaner. Politikk er med på å forme utdanningsinstitusjonene, blant annet gjennom hva som skal stå i læreplanene, som igjen er med på å strukturere fagets sosiale praksis. I den nye læreplanen, fagfornyelsen (Utdanningsdirektoratet, 2020), er idrettsaktiviteters plass i fagets undervisning nedtonet. Søkelyset vris fra prestasjoner og ferdigheter til det å øve, utforske, erfare og reflektere. Her kommer også lærebøker inn som en kunnskapskilde. Vi undersøker her noen utvalgte lærebøker som brukes av faglærere og elever i den videregående skole. ${ }^{1}$ Ved å bruke bøkenes bilder, figurer og skrevne ord undersøker vi hvilke kroppsdiskurser som framstilles, og om det finnes holdepunkter for at flere diskurser kjemper om innflytelse og dominans $i$ kroppsøvingsfagets sosiale praksis. For å undersøke dette har vi formulert følgende forskningsspørsmål: Hvilke kroppsdiskurser framstilles i lærebøker i kroppsøving på videregående skole? Og hvordan inngår disse i en kamp om innflytelse og dominans i kroppsøvingsfagets sosiale praksis?

\section{Metode}

På bakgrunn av forskningsspørsmålenes karakter valgte vi å bruke Faircloughs (1992, 2003, 2010) kritiske diskursanalyse som analytisk rammeverk. Den åpner opp for å undersøke hvilke kroppsdiskurser som framstilles, og dermed har innflytelse på kroppsforståelsen i fagets sosiale praksis. I metoden viser vi til de lærebøkene vi

\footnotetext{
${ }^{1}$ Artikkelen er basert på Cathrine Berger Myrengs masteroppgave «Start av maskinerier» - En diskursanalyse av kroppen i læreverk i kroppsøvingsfaget (Myreng, 2020). Glenn Øvrevik Kjerland og Gunn Helene Engelsrud var veiledere for masteroppgaven.
} 


\section{B. Myreng, G. H. Engelsrud E G. Ø. Kjerland}

undersøkte, og hvorfor vi valgte disse. Vi går til slutt gjennom analyseprosessen, med utgangspunkt i Faircloughs analysenivåer.

\section{Metodologisk rammeverk}

Kritisk diskursanalyse (Fairclough, 2003, 2010; Skrede, 2017) lar seg ikke begrense av kompleksiteten i sosiale fenomener, men omfavner dem ved å være tverrfaglig i sin form. Analysen går på tvers av fagdisipliner, den kan brukes til å analysere ethvert fagfelt fordi språket opererer overalt, og den er relasjonell og dialektisk, noe som åpner for å analysere fagfelt på en åpen og inkluderende måte. I analyser av kroppsøving er det en fordel med en åpen tilnærming, i og med at kunnskapen og strukturen er heterogen og ikke basert på én, men flere fagdisipliner, som fysiologi, anatomi, psykologi, pedagogikk, treningslære og profesjonskunnskap, for å nevne noen. En slik tverrfaglighet gjør det mulig å analysere kroppen i skoleomgivelsene, omgitt av disipliner og teorier i dialog med hverandre. Det tverrfaglige perspektivet gjør at vi som forskere får fram de relasjonelle dimensjonene som er i og omgir kroppen i lærebøkene (Fairclough, 2003, 2010). Gjennom et maktkritisk perspektiv undersøker vi hvordan kroppsdiskurser former og formes av sosial praksis, og vi diskuterer hvordan kroppsdiskursene i bøkene er posisjonert i institusjonelle strukturer i faget (Hågvar, 2013). Spørsmålet er om måten kroppen framstilles på i lærebøkene, inngår i relasjonelle forhandlinger med andre diskurser, eller om den står i opposisjon til dem, som for eksempel til hvordan kroppen skrives fram i læreplanverk for videregående skole.

Fairclough henviser til diskursanalyse som tekstanalyse av det talte og skriftlige. Vi analyserer det skriftlige og det visuelle som inkluderer skrevne ord, bilder og figurer. Bøkene inneholder mange bilder og figurer som gir analysen en helhetlig framstilling av kroppen. Vi valgte å analysere forholdet mellom de skrevne ordene, bildene og figurene (Kress \& Leeuwen, 2006; Traue et al., 2019), som representasjoner av verden (Fairclough, 2010; Traue et al., 2019; Wodak \& Meyer, 2015). Vi undersøkte hvordan bildene og figurene framstilles i relasjon til de skrevne ordene. Vi stilte spørsmål ved om bildene og figurene framstilles på selvstendige måter, og om de bekrefter eller motsetter seg det som uttrykkes i det skrevne ord.

\section{Utvalg av lærebøker}

Med bakgrunn i det metodologiske rammeverket har vi valgt følgende lærebøker som materiell: 360 - Kroppsøving, videregående skole er skrevet av Sletten, Enoksen, Garthe, Refsnes og Bråten, og kom ut på Gyldendal i 2009. Spinn - Kroppsøving for den videregående skolen er skrevet av Bergsjø og Kvikstad, og kom ut på Aschehoug i 2012. Gymnos - Lerebok er skrevet av Gjerset, Haugen, Holmstad, Lied, Tønnessen og Andresen, og kom ut på Cappelen Damm i 2012. Valget falt på disse lærebøkene fordi de dekker alle de tre årene ved videregående skole, og fordi de er fra tre forskjellige forlag. Slik kunne vi også undersøke forskjeller i innhold eller verdier knyttet til de ulike forlagene, hvis det skulle være aktuelt. Årene i videregående skole er en 
periode med sterk identitetsutvikling hos elevene, og den perioden i grunnopplæringen der lærebøker i kroppsøvingsfaget blir mest brukt. Det har også relevans for førsteforfatters egen pedagogiske praksis, så utvalget er både pragmatisk og strategisk (Grønmo, 2016).

Tabell 1. Presentasjon av testmateriell. Tabellen er hentet fra Myreng (2020, s. 28)

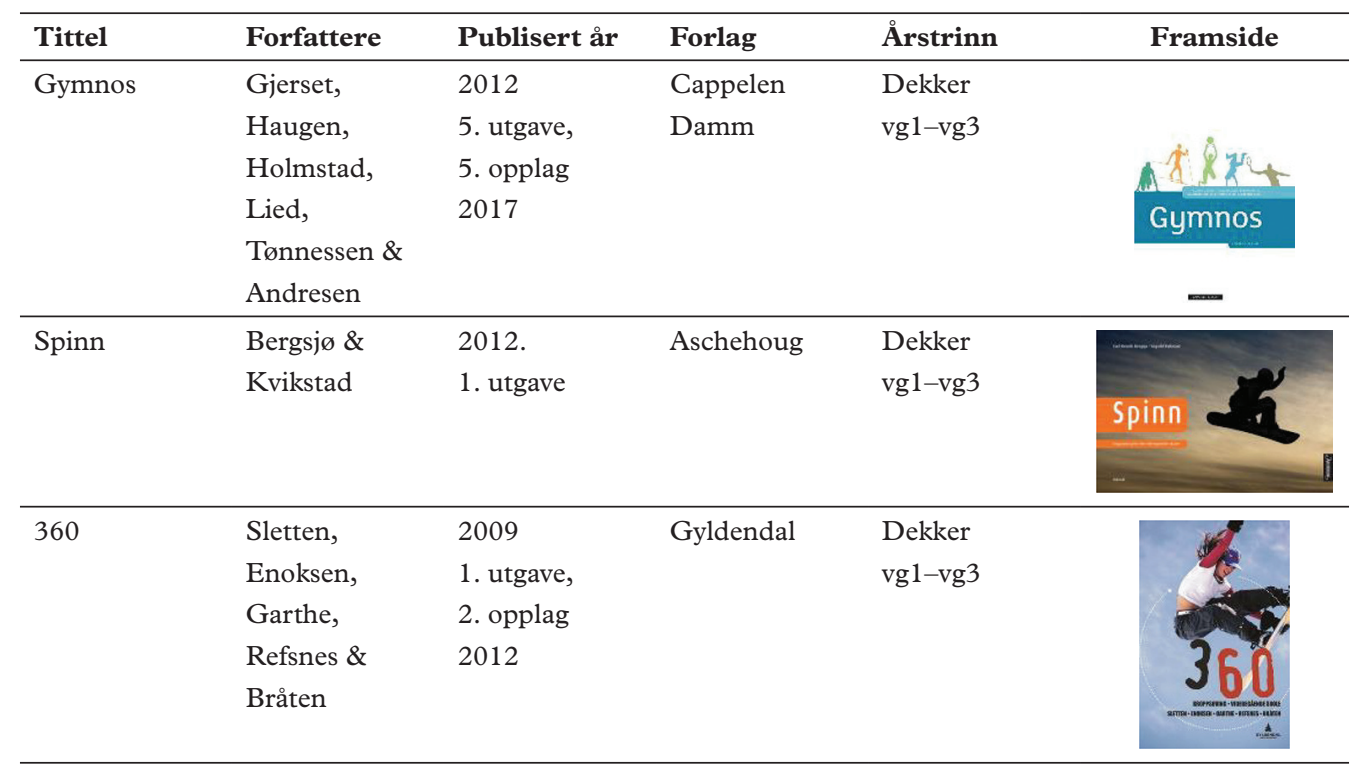

\section{Analyseprosessen}

Utgangspunktet for analysen er Faircloughs (1992, 2003, 2010) tre analysenivåer: (1) den sosiale begivenheten, (2) den sosiale praksisen og (3) de sosiale strukturene. Ifølge Fairclough kan ikke nivåene forstås direkte ut av innholdet, i og med at mening skapes i tolkningsprosessen som igjen er avhengig av bakgrunn, erfaring, verdisyn og kompetanse (Fairclough, 1992, 2003, 2010). Tolkninger som gjøres, hører til den sosiale begivenheten og prosessen mellom tekst og leser, og mellom mennesker i samhandling om innholdet (Fairclough, 1992). Det vi gjør, tenker og skriver når vi tolker lærebøkenes tekster, bilder og figurer, er å arbeide med et analytisk og kritisk forhold til oss selv i analyseprosessen. Det ble derfor viktig at funnene og tolkningene av disse ble godt beskrevet og gjort transparente (Silverman, 2015; Skrede, 2017; Thagaard, 2018). I presentasjon av funn er tekstutdrag sitert, og bilder og figurer er beskrevet slik at det skal være mulig å få et innblikk i hvordan de framstilles. Det aller beste er likevel å undersøke lærebøkene selv.

Analysematerialet, bestående av de utvalgte lærebøkene, er en del av den sosiale begivenheten, og et eksempel på hvordan kroppen framstilles gjennom skrevne ord, bilder og figurer. Den sosiale praksis er kroppsøvingsfaget i den videregående skole og omfatter planene, undervisningen og diskursene som inngår i fagets hverdag, 


\section{B. Myreng, G. H. Engelsrud \& G. Ø. Kjerland}

arenaen der elevene møter lærebøkene som en del av utdanningspraksisen. De sosiale strukturene er samfunnsmessige mønstre som synliggjøres gjennom maktforhold og ideologier. I den sosiale praksisen møtes sosiale begivenheter og sosiale strukturer. De utfordrer og avgrenser hverandre eller gir rom for utvikling, alt etter hvem som innehar den dominerende makt. Makten kommer til syne i møter mellom ulike diskurser, og maktrelasjonene er sentrale i en kritisk diskursanalyse (Fairclough, 2003, 2010, 2015).

På det først nivået $\mathrm{i}$ analyseprosessen undersøkte vi hvilken mening og verdi kroppen gis i skrevne ord, i bildene og figurene i de utvalgte lærebøkene, for å belyse hvilke kroppsdiskurser som blir framstilt. Analyseprosessen bestod av flere delprosesser. Den første var å lese gjennom bøkene for å få helhetsbildet. Den andre var å bla fram og tilbake for å finne gjentagende mønstre. I den siste fasen gikk vi mer detaljert til verks ved å kartlegge ordvalg, hvordan kroppen kommer til uttrykk i bilder og figurer, og hvordan billedlige framstillinger av kroppen samsvarer med kroppen i skrevne ord. I forskningsgruppen sendte vi e-poster fram og tilbake, og diskuterte funn og refleksjoner rundt disse. På første nivå i analysen kom vi etter hvert fram til mønstre som synliggjorde ulike menings- og verdiframstillinger av kroppen i lærebøkene.

På det andre nivået analyserte vi kroppsdiskursene i lys av den sosiale praksisen lærebøkene inngår i. Her settes de skrevne ordene, bildene og figurene sammen for å få fram hvordan ulike kroppsdiskurser spiller sammen med hverandre og språket. På denne måten viser vi hvordan kroppsdiskursene som framstilles i lærebøkene inngår i kroppsøvingsfeltets diskursorden (Jørgensen \& Phillips, 1999). Målet var synliggjøre hvordan de valgte framstillingene av kropp i lærebøkene får en kontrollerende funksjon over hvordan kroppslig variasjon organiseres. Dette gav oss igjen mulighet til å undersøke hvordan kroppsdiskursene i bøkene former den sosiale praksis gjennom interdiskursivitet (Fairclough, 2003, 2010). Høy grad av interdiskursivitet i møte mellom kroppsdiskursen i lærebøkene og læreplanen gav en indikasjon på den ideologiske og hegemoniske kampen som eksisterer mellom ulike kroppsdiskurser i faget. Det var gjennom den analytiske framstillingen av diskursorden vi kunne lokalisere ulike kroppsforståelser som inngår i og som det forhandles om i fagets sosiale praksis.

I diskusjonen om den ideologiske kampen om kroppen i kroppsøvingsfagets sosiale praksis, som forskningslitteraturen aktualiserer, har vi knyttet begrepene diskursorden, ideologi, dominans og makt tett sammen. Diskursordenen og kroppsidelogiene som kommer til syne $i$ analysen, åpner opp for å diskutere møter mellom kroppsdiskursene i lærebøkene, de hegemoniske kampene faget står i, historisk og i dag, og derfor hvordan kroppsøvingsfagets sosiale praksis bidrar til reproduksjon og produksjon av kroppen.

\section{Funn}

I denne delen presenterer vi analysen av lærebøkene og de mest framtredende kroppene. Videre belyser vi hvordan kroppsdiskursene inngår i fagets sosiale praksis, og 
til slutt diskuterer vi diskursorden i relasjon til dominerende diskurser i kroppsøvingsfaget. Framstillinger av kroppen som ble synlig i vår analyse av skrevne ord og visuelle uttrykk i bilder og figurer i lærebøkene, representerer ulike kroppsdiskurser som kommer til uttrykk i de sosiale begivenhetene. Vi har valgt å konsentrere oss om de tre mest framtredende: den idrettsaktive kroppen, den biologiske kroppen og den atletiske kroppen. Den atletiske kroppen blir utdypet med noen underliggende framstillinger som er avgjørende i diskusjonen om hvilke kropper som favoriseres og marginaliseres.

\section{Den idrettsaktive kroppen}

På den ene lærebokens framside er det en illustrasjon av kropper som utfører ulike idrettsaktiviteter (Gjerset et al., 2012). De to andre framsidene har bilder av snøbrettkjørere som gjør triks høyt oppe i luften (Bergsjø \& Kvikstad, 2012; Sletten et al., 2009). Innholdsfortegnelsene lister opp idrettsaktiviteter som badminton, basketball, fotball, friidrett og innebandy (Bergsiø \& Kvikstad, 2012, s. 3; Gjerset et al., 2012, s. 4-5; Sletten et al., 2009, s. 4-5). Alle lærebøkene har overskrifter som inneholder ord og uttrykk som styrke/styrketrening, utholdenhet/utholdenhetstrening, bevegelighetstrening, spenst/spensttrening, hurtighet/hurtighetstrening, teknikk/ teknikktrening, koordinasjon/koordinasjonstrening og skader/idrettsskader. Søkelyset er på effekten av trening og vises eksempelvis slik:

Skal kroppen vokse, trives og utvikle seg, må den brukes. Mennesket er nemlig skapt til bevegelse og fysisk aktivitet. Du trenger fysiske egenskaper som utholdenhet, styrke og bevegelighet for at du skal kunne drive med en eller annen form for fysisk aktivitet. Når du danser, går, jogger eller spiller fotball, skjer det mye i kroppen din. (Bergsjø \& Kvikstad, 2012, s. 9)

I sitatet over knyttes kroppen til bruk. Fysiske aktiviteter og idrettsaktiviteter beskrives som noe mennesker er skapt til, eller som kroppens opprinnelige formål. Fra en stadfesting av at mennesker er skapt til bevegelse og fysisk aktivitet, går skrevne ord videre med en personlig henvendelse til et "du»: Du trenger å forbedre dine fysiske egenskaper som styrke, utholdenhet, spenst og bevegelighet, som om kroppen skapes gjennom idrettsaktivitet.

Et gjennomgående trekk i lærebøkene er at kroppene avbildes i aktivitet, sjelden i ro. Det frambringes en mal for hvordan man skal oppnå den aktiviserte, slanke, veltrente kroppen gjennom trening og kosthold. Ulike aktiviteter og idretter er beskrevet med oppskrifter på riktige teknikker, slik at de kan utføres på bestemte måter. ${ }^{2}$ I egne kapitler eller avsnitt presenteres kontroll og testing som en del av dette. De ulike lærebøkene framstiller og vektlegger dette ulikt (Bergsjø \& Kvikstad, 2012,

2 (Bergsjø \& Kvikstad, 2012, s. 178-182, 184, 186, 187-193, 196, 199-201, 203-209, 217-220, 236, 253; Gjerset et al., 2012, s. 198-200, 205-208, 222-224, 227-229, 232-234, 239, 241-245, 251-254, 257-258, 264-266, 270, 274-275, 281-282, 287-288; Sletten et al., 2009, s. 73, 212$213,219,221-224)$ 


\section{B. Myreng, G. H. Engelsrud \& G. Ø. Kjerland}

s. 133-134; Gjerset et al., 2012, s. 185-186; Sletten et al., 2009, s. 143-148), og viser i tillegg bilder av testing av oksygenopptak (Bergsjø \& Kvikstad, 2012, s. 37), tidtaking (Gjerset et al., 2012, s. 45) og pulsmåling (Bergsjø \& Kvikstad, 2012, s. 35; Gjerset et al., 2012, s. 33; Sletten et al., 2009, s. 140), noe som støtter opp under skrevne ord i lærebøkene. Kontroll og testing er en del av treningslære innen idretten og idrettsfagene.

\section{Den biologiske kroppen}

I lærebøkene finner vi beskrivelser av kroppens fysiologi, oppbygning/anatomi, biomekanikk, funksjon, og hva som skal til for at kroppen skal kunne prestere bedre og utvikle ferdigheter. Metodene er å manipulere ulike biologiske deler, slik at de kan arbeide sammen for å oppnå forbedring. Gjerset et al. skriver:

Hjertet og blodårene utgjør et lukket system. Blodet i kroppen sirkulerer i to kretsløp, det lille og det store. [...] Vi kan si at hjertet er en viktig motor når du er i aktivitet, og at kvaliteten på hele sirkulasjonssystemet ditt er avgjørende for din utholdenhet. (Gjerset et al., 2012, s. 37)

Sitatet er et eksempel på innramming av kroppen i det biologiske kunnskapsfeltet. Hjertet framstilles som en mekanisk del som inngår i transportmidler, og kvaliteten på denne delen er avgjørende for prestasjon. Det er også andre eksempler hvor kroppens biologi framstilles som deler i en motor: «På samme måte som en bilmotor kan omsette den kjemiske energien i bensinen til å skape en hensiktsmessig fart, kan kroppen omsette den kjemiske energien i maten til mekanisk arbeid» (Sletten et al., 2009, s. 22). Overskriftene "Oppvarming - start av maskineriet", "Anaerob energiomsetning - kroppens reservemotor» og «Styrke - stål i bein og armer» (Sletten et al., 2009 , s. $8,16,32$ ) viser sammenligninger med maskiner, motorer og uorganiske materialer og kroppsdeler.

En forbedring av ferdigheter med søkelys på biomekanikkens delelementer og bruk av isolerte kroppsdeler går igjen i bøkene. Et eksempel er: «Høyre arm er i overgangen fra trekkfasen til skyvfasen. Armen er bøyd ca. 90 grader i albueleddet, og den har en stilling som gir et godt grep på vannet. Venstre arm er midt i framføringen» (Gjerset et al., 2012, s. 242). Det mekaniske synet, innrammet i en biomekanisk representasjon av kroppen, framstilles på flere steder.

Det nære forholdet til fysiologi og biomekanikk i innholdet i lærebøkene viser at det naturvitenskapelige fagfeltet og dualismen mellom den fysiske kroppen og det tenkende mennesket er sterkt nærværende. De fysiologiske elementene i trening danner selve rammen for bøkene giennom vektlegging av oppvarming, utholdenhet, styrke, bevegelighet, spenst og hurtighet (Bergsjø \& Kvikstad, 2012, s. 3; Gjerset et al., 2012, s. 4-5; Sletten et al., 2009, s. 4-5). I alle tre lærebøkene blir kroppen framstilt som fragmentert gjennom en anatomisk og fysiologisk oppdeling som representert ulike deler av helheten. Denne framstillingen konstituerer en kropp som består av deler satt inn i et maskinelt system, og som kan øke utholdenhet, styrke, hurtighet og spenst. 


\section{Den atletiske kroppen}

Diskursene som framstilles over står ikke i motsetning til hverandre, men underbygger og bekrefter hverandre gjennom den atletiske kroppen. Å delta i idrettsaktivitet er én side av den atletiske kroppen, å se atletisk ut er en annen side. «Unge og eldre er opptatt av kropp og utseende, og de vil gjerne se veltrente ut» (Bergsjø \& Kvikstad, 2012, s. 42). Det å være veltrent blir et ideal som gielder alle, og, presentert i en slik form, også et mål for faget. Budskapet blir forsterket gjennom bruk av bilder av topptrente idrettsutøvere i friidrett, tennis, turn, padling, roing, sykling, orientering, basketball, fotball og volleyball, som viser definerte muskler. ${ }^{3}$ Idrettsutøvere er kledd for trenings- og konkurransesituasjoner i sine idretter, ergo er mange avbildet med lite eller ettersittende klær og med nakne armer og ben, som får stor plass i det å synliggiøre idrettsutøverne i aktivitetene. Et atletisk utseende avbildet $i$ en estetisk framstilling av idrettsaktive kropper, karakteriserer den gjennomgående bildebruken i lærebøkene. Diskursen favner om både kroppen i bevegelse, handling og utseende. Men det er ikke bare i sammenheng med idrettsprestasjon og utseende at den atletiske kroppen kommer til uttrykk. Den kommer også til uttrykk i oppnåelse av et godt sosialt liv. Den er med på å skape trivsel med likeverdige venner og giøre en aktiv livsutfoldelse mulig (Bergsjø \& Kvikstad, 2012, s. 8; Gjerset et al., 2012, s. 9, 12, 20, 35, 142). Det handler om å kultivere kroppen inn et bilde som samtidig bygger på idrettens og biologiens premisser.

I den atletiske kroppen finner vi også underliggende framstillinger av kroppen. Her finner vi bilder og tekster fra kroppen i handikappidretter, sterk er den nye tynn-kroppen, den kjønnsspesifikke idealkroppen og den sunne kroppen. Når personer med funksjonsnedsettelser er avbildet, framstilles de ofte som atletiske kropper deltakende i idrettskonkurranser. De er i konkurransesituasjoner med startnummer på, som for eksempel slalåmkjøring med racingstol (Bergsjø \& Kvikstad, 2012, s. 97, 190). Den fargede kroppen framstilles også på denne måten, gjennom langdistanseløperen (Gjerset et al., 2012, s. 31), basketballspilleren (Bergsjø \& Kvikstad, 2012, s. 233, 238; Gjerset et al., 2012, s. 145, 255; Sletten et al., 2009, s. 159, 179) og sprinteren (Bergsjø \& Kvikstad, 2012, s. 185; Gjerset et al., 2012, s. 21, 58; Sletten et al., 2009, s. 26, 96, 186). Når den fargede kroppen tilhører kvinner, bæres store tønner med vann på hodet (Sletten et al., 2009, s. 75). Framstillingen av kjønn inneholder kategoriene jenter og gutter gjennom en relativ lik fordeling av bilder mellom disse to kjønnskategorier og giennom bruk av begreper som partnere, spillere, medspillere og motstandere, du og dere. Her er det ingen bilder av transkjønnede eller bruk av pronomenet hen. Forskjellene eksisterer kun mellom jenter og gutter, og kommer fram når målsettinger, idealer, verdier og utfordringer beskrives. Det legges vekt på at jenter og gutter har ulike mål med treningen, og ulike tanker om hvordan de helst vil se ut. Eksemplifisert her:

${ }^{3}$ (Bergsjø \& Kvikstad, 2012, s. 29, 97, 140, 147, 177-178, 183, 185, 187, 189, 202, 209, 221-233; Gjerset et al., 2012, s. 6, 21, 31, 52, 53, 58, 82, 132, 145, 148-149, 204, 210, 255; Sletten et al., 2009 , s. 8, 14, 17, 22, 29, 98,189, 225). 


\section{B. Myreng, G. H. Engelsrud \& G. Ø. Kjerland}

Jenter er stort sett mer opptatt av kroppen sin enn gutter. [...] En ideell jentekropp er tynn, men veltrent, har fine pupper og stram rumpe, og krones med et pent ansikt. For noen jenter kan det være viktigere å trene for å få en fin kropp enn å prestere sportslig. (Bergsjø \& Kvikstad, 2012, s. 142)

Den sunne kroppen knyttes til individualitet, trening, fysisk aktivitet, sunnhet og den slanke atletiske kroppen. Her noterer vi at den overvektige kroppen er fraværende. Den sunne, atletiske kroppen representerer også det å ha godt immunforsvar og god helse. Med overskrifter som "Ansvar for egen helse» (Gjerset et al., 2012, s. 170; Sletten et al., 2009, s. 140), og tekstinnhold som «Din helse er ditt eget ansvar» (Bergsjø \& Kvikstad, 2012, s. 153), framstilles god helse som noe elevene selv har ansvar for, og trening blir middelet for å oppnå dette.

\section{Diskusjon}

I innledningen peker vi på at lærebøkene gjør noe i fagets sosiale praksis. Funnene fra analysen av lærebøkene indikerer at de er med på å rekonstruere en diskursiv orden som har eksistert i kroppsøvingsfagets sosiale praksis over tid. Dette er en diskursorden dominert av disiplinerte og normaliserte kropper, rammet inn av idrettens prestasjonsdiskurs og helsediskursens sunnhetsidealer (Augestad, 2003; Kirk, 2010; Kirk et al., 1997; Kjerland, 2015; Moen, 2011; Moen \& Rugseth, 2018; Svendsen \& Svendsen, 2017; Tinning, 2010; Aartun et al., 2020). Konsekvensene er at lærebøkene reproduserer en diskursiv orden som domineres av atletiske kropper, innlemmet i idrettens prestasjonslogikk, utviklet gjennom manipulering av kroppens biologiske system. I lærebøkene kommer dette til uttrykk gjennom bruk av tekster og bilder som beskriver og avbilder kropper som utøver idrettsaktiviteter, som inngår i en biologisk maskin-analogi, som er sunne, ser bra ut og presterer i idrett.

I lærebøkene blir kropper som avviker fra normen, som den fargede kroppen, kjønnede kroppen, overvektige kroppen eller kroppen med nedsatt funksjonsnedsettelse, legitimert og anerkjent gjennom å bli avbildet som atletiske kropper aktive i idrett. Eksempelvis reproduseres framstillingene av den fargede kroppen i sprinteren, basketballspilleren og langdistanseløperen, som er innarbeidede stereotypier av fargede idrettsutøvere (Dowling, 2017; Gullestad, 2007; Langeland, 2007). Dette er med på å videreføre verdier og holdninger som kan virke fremmedgiørende på flere elevgrupper i videregående skole.

Fairclough (2010) foreskriver en løsning for å endre eksisterende diskurser, ideologier og forståelser av fenomener, ved at de denaturaliseres med nye diskurser, ideologier og forståelser. Lærebøkene vi har analysert, inngår i og bidrar til naturaliseringen av kroppsforståelsen elevene møter i kroppsøvingsfaget, i betydning at de framstår som normale i fagets sosiale praksis (Augestad, 2003; Kirk, 2010; Kirk et al., 1997; Kjerland, 2015; Tinning, 2010; Öhman \& Quennerstedt, 2008; Aartun et al., 2020; Aasland \& Engelsrud, 2017). Lærebøkene utfordrer derfor ikke hva som kan oppstå når elever ikke passer inn i bildet av den normale eller 
naturaliserte kroppsforståelsen i faget. Det skaper ulike verdsettinger av kroppen, noe som fører til at noen kropper inkluderes, mens andre ekskluderes. At det forhandles om hvilke kropper som skal inkluderes i kroppsøvingsfaget, er et vesentlig spørsmål i overgangen til nye læreplaner med fagfornyelsen (LK20). Handlingsrommet for og kravet til inkludering og endring er tydelig kommunisert fra Utdanningsdirektoratet (2020). Aasland et al. (2020) stiller seg likevel tvilende til om fagfornyelsen og endringene i læreplanen er tilstrekkelige tiltak i kampen mot idrettens dominerende posisjon i faget. De mener at overgangen fra å undervise $\mathrm{i}$ ferdighetsutvikling $\mathrm{i}$ aktiviteter, til å benytte aktiviteter til å utforske, øve, erfare og reflektere, er en positiv utvikling i faget. Endringene i læreplanen krever og medvirker til at diskursene knyttet til kroppen som en idrettsutøvende biologisk maskin må problematiseres. Dette mener vi kan medføre at mange får øynene opp for makten som har rådet og fortsatt råder over kroppen i faget, og i verdsettingskulturer i samfunnet.

Fagfornyelsens (Utdanningsdirektoratet, 2020) dreining fra prestasjoner og ferdigheter til det å øve, utforske, erfare og reflektere, har åpnet lærerens handlingsrom (Aasland et al., 2020) i en retning som ikke er synlig i de lærebøkene vi har analysert. Bøkene er derfor ikke godt egnet som middel til å imøtekomme læreplanverkets fokus, eller til å ta et oppgjør med fagets instrumentelle idrettspraksis til fordel for en mer helhetlig faglig, pedagogisk danningstenkning, bunnet i en kroppsfenomenologisk tenkning jf. Sæle (2017). Derfor er det viktig, som både Larsson (2021) og Sæle og Hallås (2020) skriver, å argumentere for at i kroppsøvingslærerutdanning i dag skal lærerstudentene utfordres til å reflektere over ideologier som er aktive i faget, arbeide med forskning som støtter opp under det å ta kritisk stilling til kroppsidealer, og stille spørsmål ved hvilke kropper som skal ha verdi i faget.

Vår analyse av lærebøkene avdekket tre framtredende kroppsdiskurser, som samlet sett er med å konstituere fagets sosiale praksis. Det å leve med funksjonsnedsettelse, være overvektig, kvinne eller ha ulike etnisiteter får en posisjon som utenforstående kropper slik de presenteres i bøkene, og teller kun med dersom de også innrammes i den idrettsaktive og atletiske kroppsdiskursen. Det er kun det å beskjeftige seg med fysisk aktivitet og idrett, og være slank og veltrent, som inkluderes som innenfor normen. Den ledende bilde- og ordbruken skaper og manifesterer elevenes verden når de blar i og leser lærebøkene, og, ifølge Faircloughs perspektiv, tar elevene med seg dette når de operer er innenfor utdanningens sosiale praksis. Basert på tidligere studier kan diskursordenen som framtrer i lærebøkene vi analyserte få en sterk posisjon, da de har støtte i den hegemoniske idrettsdiskursen som har påvirket faget siden 1920-tallet (Augestad, 2003) og hatt dominans siden 1950-tallet (Kirk, 2010). Analysen vi har giort av de utvalgte lærebøkene er med på å vise fram et bestemt kropps- og verdisyn, hentet fra idretten, basert på en tankegang der den fysiske kroppen ikke uten videre kobles til det tenkende mennesket. Lærebøkene står dermed i et gjensidig forhold til de sosiale strukturene som har formet faget over tid og giengir og (re)produserer allerede eksisterende kroppsforståelser og kroppssyn. En sosial praksis hvor lærere og 


\section{B. Myreng, G. H. Engelsrud \& G. Ø. Kjerland}

elever møtes, og hvor deres felles forståelse av kroppen formes, kan dermed bli et sted som opprettholder eller endrer en slik forståelse.

\section{Avsluttende betraktning}

I analysen av lærebøkene var det den idrettsaktive kroppen, den biologiske kroppen og den atletiske kroppen som var mest framtredende. Disse, i tillegg til noen underdimensjoner i den atletiske kroppen, går sammen og skaper diskursorden. Denne diskursorden inngår i og er med å forme en sosial praksis som har vært kjent i kroppsøvingsfaget over tid. Den idrettslige og atletiske kroppsdiskursen, innrammet i dualisme som reduserer kroppen til en biologisk maskin, gir lærebok-kroppen en betydelig plass $\mathrm{i}$ den ideologiske kampen i faget, hvor kunnskap og struktur trekkes i flere retninger. Diskurser om kroppen og ideologier i kroppsøvingsfaget skapes gjennom ideologiske forståelser som brytes mot hverandre, og dermed åpner det for muligheter for endring $i$ fagets sosiale praksis. Basert på våre funn og de konkurrerende framstillingene av kroppen som eksisterer, er det grunn til å stille spørsmål ved hva faglærerutdanningsinstitusjonene, skolene, forlagene, lærebokforfattere og lærerne giør for arbeide kritisk med hvordan kroppen framstilles og giøres i kroppsøvingsfaget. Et spørsmål er: Hva slags diskusjoner skal føres om hvilke verdsettingskulturer kropper innrammes i? Som Sæle og Hallås (2020) anbefaler, bør det i framtidens kroppsøvingsfag, i både forskning og undervisning, legges mer vekt på å forstå og møte elevene som sansende og utforskende i sin egen læring. Ved å synliggiøre lærebøkenes framstilling av kroppen og den makten som ligger i måten å kommunisere på, har vi fått fram at lærebok-kroppen reproduserer stereotype kroppssyn og dermed kan svekke kroppens betydning for elevers personlige (unike) læring og (ut)danning. Lærere i kroppsøvingsfaget vil, ved å støtte seg på lærebøkene, kunne stå i fare for å reprodusere en snever forståelse av kroppen. Og et skolefag som skal være for alle elever kan, gjennom den sosiale praksis, være med på å ekskludere elever som ikke faller inn under de kroppsdiskurser som er rådende. Den nye læreplanen i kroppsøving legger imidlertid premisser for at alle elever skal regnes som verdifulle deltagere i undervisningen, uavhengig av kjønn, seksualitet, etnisitet, sosial klasse, bosted og funksjonsnedsettelse. Lærernes utfordringer blir å fortolke og realisere læreplanen for å utvikle fagets sosiale praksis. Om framstillingene av kroppen i lærebøkene som er representerer i denne studien vil få betydning i fagets sosiale praksis i framtiden gjenstår å se. Men mest nærliggende å anta er at kroppsøvingsfaget går inn i en framtid preget av ideologiske kamper mellom det noen vil kalle fortidens og framtidens kroppssyn og kroppsforståelser.

\section{Forfatteromtale}

Cathrine Berger Myreng er avdelingsleder for idrett og studiespesialisering ved Valdres vidaregående skule, Innlandet fylkeskommune. Hun er utdannet faglærer 
i kroppsøving, idrettsfag, naturfag og rettslære, og har jobbet ti år som lærer. Hun har tatt en mastergrad i læring og undervisning med spesialisering i kroppsøving ved Høgskulen på Vestlandet, Sogndal. Tittelen på masteroppgaven var «Start av maskineriet» - En diskursanalyse av kroppen i læreværk i kroppsøving.

Gunn Helene Engelsrud er professor ved Høgskulen på Vestlandet, Fakultet for lærerutdanning, kultur og idrett. Hun har en særlig kompetanse i kvalitativ og fenomenologisk forskning innen tema som kropp, bevegelse, erfaring, samt undervisning og læring i høyere utdanning. Blant hennes siste publikasjoner er: Movement as relations: Preverbal, conscious and affected. I R. Bailey, J. P. Agans, J. Côté, A. Daly-Smith \& P. D. Tomporowski (Red.), Physical activity and sport during the first ten years of life (kap. 3). Routledge (2021).

Glenn Øvrevik Kjerland er førsteamanuensis ved Høgskulen på Vestlandet, Avdeling for utvikling av læring og undervisning. Etter endt hovedfag i idrettsvitenskap begynte han å undervise ved Göteborgs universitet, hvor han senere gikk opp til doktorseksamen i pedagogikk, med spesielt søkelys på tilrettelegging for aktivitet som støtter utvikling av undervisningskompetanse i kroppsøvingslærerutdanningen. Han har bred faglig bakgrunn fra pedagogikk, kroppsøving og universitets- og høyskolepedagogikk, og særlig kompetanse innen tema som læring, utvikling, kultur historisk teori og kvalitativ metode.

\section{Referanser}

Augestad, P. (2003). Skolering av kroppen. Om kunnskap og makt i kroppsøvingsfaget [Doktorgradsavhandling, Høgskolen i Telemark]. USN Open Archive. http://hdl.handle.net/11250/2590013.

Azzarito, L. (2009). The Panopticon of physical education: Pretty, active and ideally White. Physical Education and Sport Pedagogy, 14(1), 19-39. https://doi.org/10.1080/17408980701712106

Bergsjø, C.-H. \& Kvikstad, I. (2012). Spinn. Kroppsøving for den videregående skolen. Aschehoug.

Dowling, F. (2017). "'Rase' og etnisitet? Det kan ikke jeg si noe særlig om - her er det 'Blenda-hvitt”!». Norsk pedagogisk tidsskrift, 101(03), 252-265. https://doi.org/10.18261/issn.1504-2987-2017-03-06

Fairclough, N. (1992). Discourse and social change. Polity Press.

Fairclough, N. (2003). Analysing discourse. Textual analysis for social research. Routledge.

Fairclough, N. (2010). Critical discourse analysis. The critical study of language (2. utg.). Routledge.

Fairclough, N. (2015). Language and power (3. utg.). Routledge.

Gjerset, A., Haugen, K., Holmstad, P., Lied, R., Andresen, A. \& Tønnesen, E. (2012). Gymnos. Larebok (5. utg.). Cappelen Damm.

Grønmo, S. (2016). Samfunnsvitenskapelig metoder (2. utg.). Fagbokforlaget.

Gullestad, M. (2007). Misjonsbilder. Bidrag til norsk selvforståelse. Universitetsforlaget.

Hågvar, Y. B. (2013). Djevelen ligger i diskursen - en kritisk diskursanalyse av Marte Krogh-saken i VG. Norsk medietidsskrift, 20(3), 200-222. https://doi.org/10.18261/ISSN0805-9535-2013-03-02

Jørgensen, M. W. \& Phillips, L. (1999). Diskursanalyse som teori og metode. Roskilde Universitetsforlag.

Kirk, D. (2010). Physical education futures. Routledge. https://doi.org/10.4324/9780203874622

Kirk, D., Macdonald, D. \& Tinning, R. (1997). The social construction of pedagogic discourse in physical education teacher education in Australia. The Curriculum fournal, 8(2), 271-298. https://doi.org/ 10.1080/0958517970080206

Kjerland, G. Ø. (2015). Å lcere å undervise $i$ kroppsøving. Design for utvikling av teoribasert undervisning og kritisk refleksjon $i$ kroppsøvingslcererutdanningen [Doktorgradsavhandling, Göteborgs universitet]. GUPEA. http:// hdl.handle.net/2077/39590 


\section{B. Myreng, G. H. Engelsrud $\mathcal{E}$ G. Ø. Kjerland}

Kress, G. \& Leeuwen, T. v. (2006). Reading images. The grammar of visual design (2. utg.). Routledge.

Langeland, F. (2007). Harde kropper. En kulturvitenskapelig analyse av maskulinitetskonstruksjoner $i$ Dagbladets Sportsmagasinet [Masteravhandling, Universitetet i Bergen]. BORA. https://hdl.handle.net/1956/2685

Larsson, H. (Red.). (2021). Learning movements. New perspectives of movement education. Routledge.

Moen, K. M. (2011). "Shaking or stirring"? A case-study of physical education teacher education in Norway [Doktoravhandling, Norges idrettshøgskole]. http://hdl.handle.net/11250/171359

Moen, K. M. \& Rugseth, G. (2018). Perspektiver på kropp i kroppsøvingsfaget i skolen og i faglærerutdanningen i kroppsøving. Fournal for Research in Arts and Sports Education, 2(1), 154-168. https://doi.org/10.23865/ jased.v2.1052

Myreng, C. B. (2020). «Start av maskineriet» - En diskursanalyse av kroppen i lereverk $i$ kroppsøvingsfaget [Masteroppgave, Høgskulen på Vestlandet]. HVL Open. https://hdl.handle.net/11250/2670676

Silverman, D. (2015). Interpreting qualitative data (5. utg.). Sage.

Skrede, J. (2017). Kritisk diskursanalyse. Cappelen Damm Akademisk.

Sletten, S.-H., Enoksen, E., Garthe, I., Refsnes, P. E. \& Bråten, M. (2009). 360 Kroppsøving - videregående skole. Gyldendal.

Svendby, E. B. (2013). "feg kan og jeg vil, men jeg passer visst ikke inn»: En narrativ studie om barn og unges erfaringer med kroppsøvingsfaget når de har en sjelden diagnose (fysisk funksjonshemning) [Doktorgradsavhandling, Norges idrettshøgskole]. http://hdl.handle.net/11250/171353

Svendsen, A. M. \& Svendsen, J. T. (2017). Contesting discourses about physical education: A critical discourse analysis of 20 textbooks used in physical education teacher education in Denmark. European Physical Education Review, 23(4), 480-498. https://doi.org/10.1177/1356336X16657279

Sæle, O. O. (2017). Mind the gap! Kroppsøvingsfaget - mellom ideologi og virkelighet. Bedre skole, 29(4), 14-19. https://www.utdanningsnytt.no/files/2019/06/27/Bedre\%20Skole\%204\%202017.pdf

Sæle, O. O. \& Hallås, B. O. (2020). Kroppsøving i femårig leererutdanning. Gyldendal.

Thagaard, T. (2018). Systematikk og innlevelse. En innføring i kvalitative metoder (5. utg.). Fagbokforlaget.

Tinning, R. (2010). Pedagogy and human movement. Theory, practice, research. Routledge.

Traue, B., Blanc, M. \& Cambre, C. (2019). Visibility and visual discourses: Rethinking the social with the image. Qualitative Inquiry, 25(4), 327-337. https://doi.org/10.1177/1077800418792946

Utdanningsdirektoratet. (2020). Lcereplan i kroppsøving (KRO01-05) https://www.udir.no/1k20/kro01-05

Walseth, K. \& Tidslevold, T. (2020). Young women's constructions of valued bodies: Healthy, athletic, beautiful and dieting bodies. International Review of the Sociology of Sport, 55(6), 703-725. https://doi. org/10.1177/1012690218822997

Wodak, R. \& Meyer, M. (2015). Critical discourse studies: History, agenda, theory and methodology. I R. Wodak \& M. Meyer (Red.), Methods of critical discourse studies (3. utg., s. 1-22). Sage.

Öhman, M. \& Quennerstedt, M. (2008). Feel good - be good: Subject content and governing processes in physical education. Physical Education and Sport Pedagogy, 13(4), 365-379. https://doi.org/10.1080/ 17408980802353339

Aartun, I., Walseth, K., Standal, Ø. F. \& Kirk, D. (2020). Pedagogies of embodiment in physical education - a literature review. Sport, Education and Society, 1-13. https://doi.org/10.1080/13573322.2020.1821182

Aasland, E. (2019). Konstitueringen av «kroppsøving». En diskursteoretisk studie av undervisningspraksiser $i$ videregående skole [Doktorgradsavhandling]. OsloMet - storbyuniversitetet.

Aasland, E. \& Engelsrud, G. (2017). «Det er lett å se hvem av dere som har god innsats». Om elevers innsats og lærerens blikk i kroppsøving. Fournal for Research in Arts and Sports Education, 1(3), 5-17. http://dx.doi. org/10.23865/jased.v1.889

Aasland, E., Moen, K. M. \& Mathisen, G. (2020). Et fornyet kroppsøvingsfag - noen fagdidaktiske betraktninger. Bedre skole, (1), 36-40. https://user-nc1yu2a.cld.bz/Bedre-skole-nr-1-2020/36/ 